\title{
State of Conservation and Periodic Reporting - A Way for Better Preservation and Sustainable Development of the World Heritage Sites
}

\section{Sergiu MUSTEAȚĂ}

\begin{abstract}
Since 1972 UNESCO has established a frame of protection for cultural and natural heritage (Convention concerning the protection of the World Cultural and Natural Heritage) and the "World Heritage List", which it considers as having outstanding universal value. In 1994, at the Nara Conference, the Document on Authenticity was established, stating that "the protection and enhancement of cultural and heritage diversity in our world should be actively promoted as an essential aspect of human development". Today, many factors affect the authenticity and integrity of cultural heritage: intensive tourism, excessive restoration works, new inappropriate investments or uncorrelated private interventions, etc. The debates on cultural heritage research, preservation and management have increased in recent years as the effect of UNESCO standards, namely to establish "an effective system of collective protection of the cultural and natural heritage of outstanding universal value, organized on a permanent basis and in accordance with modern scientific methods". The problem of preservation, management, and promotion of heritage is of crucial importance from many points of views: scientific, technologic, socio-economic, and cultural.

Romania owns eight properties forming part of the World Heritage List (two natural and six cultural sites). Another fifteen properties are included in the Tentative List. The reports concerning the situation of the World Heritage Sites in Romania are done periodically, but most are just a formality without any strategic development and sustainable management plans. There is a significant discrepancy between the visibility and importance given to the sites included on the World Heritage List. These problems could be prevented through better monitoring and management methods, while regional cooperation could be a driver for identifying the best ways to do so at a regional level. Only a common and integrated approach will make it possible to enrich UNESCO standards of preservation and maintain the World Heritage Site status.
\end{abstract}

Keywords: World Heritage List, heritage management, state of conservation, evaluation, site monitoring, Romania, UNESCO.

\section{Introduction}

In 2017 the most countries around the World celebrated the $45^{\text {th }}$ Anniversary of the UNESCO Convention for protection of World Cultural and Natural 
Heritage, one of the international treaties ${ }^{1}$ Cultural Heritage is a common resource of people across the world, representing humanity's relationship with the past and its traditions. Cultural heritage is diverse, and people have a common responsibility to understand and safeguard it for future generations. The main goal of the 1972 UNESCO Convention is to protect the cultural and natural heritage of humankind at international level. But, to become a part of this international convention and implement it at the national level it is a long way and process. ${ }^{2}$

Since 1972 UNESCO has established a frame of protection for cultural and natural heritage (Convention concerning the protection of the World Cultural and Natural Heritage) and the "World Heritage List", which it considers as having outstanding universal value. The 1972 Convention established the World Heritage Committee, which is an international body of 21 state parties, elected for 4 years that decide during their annual meetings on including or excluding sites into the World Heritage List. In 1994, at the Nara Conference, the Document on Authenticity was established, stating that "the protection and enhancement of cultural and heritage diversity in our world should be actively promoted as an essential aspect of human development".

For better preservation policies, each country has to transpose the World Heritage Convention in the national legislation. The harmonisation of the national legislation is a long and bureaucratic process. But, for application to the World Heritage List, each State Parties, depending on its political and administrative system, has to take real steps for implementation of the Convention. In most of the countries, the International Treatment, as soon as it is signed and ratified is more significant than national laws, but for its practical implementation, the Convention has to be transposed in the national legislation. Romania is among 193 states which signed the 1972 World Heritage Convention in 1990. But, the real implementation of the Convention started just in 2000 when the first legal instrument was approved by the Government on the establishment of measures for the protection of historical monuments belonging to the World Heritage List. ${ }^{3}$ In 2004 the Government approved Methodology on the monitoring of historical monuments listed in the Wor-

1 Basic Texts of the 1972 World Heritage Convention, Paris, UNESCO World Heritage Centre, 2017. Francesco Francioni, Federico Lenzerini, The 1972 World Heritage Convention: a commentary, Oxford: Oxford University Press, 2008.

2 B. Gaillard, Historical perspective on the transposition of the 1972 UNESCO World Heritage Convention in the national legislation of its states parties. Historical Perspective of Heritage Legislation. Balance between Laws and Values, Tallinn: ICOMOS Estonia, 2017, pp. 56-62.

3 Legea 564/2001 pentru aprobarea și modificarea OG 47/2000 privind stabilirea unor măsuri de protecție a monumentelor istorice care fac parte din Lista Patrimoniului Mondial. 
ld Heritage List and the Methodology on the elaboration and content of the plans for the protection and management of historical monuments listed in the World Heritage List. ${ }^{4} \mathrm{~A}$ few years later a Government Decision on establishing the necessary measures for the financing, elaboration, and updating of the spatial planning and urbanization documentation for the historical monuments that are part of the World Heritage List was approved. ${ }^{5}$ In 2010 The Government approved Program for the protection and management of historical monuments included in the UNESCO World Heritage List as amended by the Government Decision no. 1102 of 2 November 2011.6 During the last 27 years, Romania has developed various rules and laws concerning heritage preservation 7 , but there is still place for better improvement of the national legal framework, especially concerning the management of cultural and natural heritage, fighting black archaeology, illegal traffic of antiquities, etc., which affects the World Heritage Sites.

In 2018, the World Heritage List comprised 1092 properties from 167 countries, including 845 cultural sites, 209 natural sites, and 38 mixed sites. Romania had inscribed eight sites (six cultural and two natural) until 2017: the Danube Delta (1991; natural site), Churches of Moldavia (1993), Monastery of Horezu (1993), Villages with Fortified Churches in Transylvania (1993), Dacian Fortresses of the Orăștie Mountains (1999), Historic Centre of Sighișoara (1999), Wooden Churches of Maramureș (1999) and Ancient and Primeval Beech Forests of the Carpathians and Other Regions of Europe (2017). According to the World Heritage Centre official site, another fifteen properties are included into the Tentative $\mathrm{List}^{8}$. But, in 2017, the National Institute of Heritage finished the updating process of the Tentative List, which included 18 cultural sites and 1 natural site. ${ }^{9}$

4 Hotărârea Guvernului nr. 493/2004 pentru aprobarea Metodologiei privind monitorizarea monumentelor istorice înscrise în Lista patrimoniului mondial şi a Metodologiei privind elaborarea și conținutul-cadru al planurilor de protecție și gestiune a monumentelor istorice înscrise în Lista patrimoniului mondial.

5 Hotărârea Guvernului nr. 738/2008 privind stabilirea măsurilor necesare în vederea finanțării, elaborării și actualizării documentațiilor de amenajare a teritoriului și urbanism pentru zonele cu monumente istorice care fac parte din Lista Patrimoniului Mondial.

${ }^{6}$ Hotărârea Guvernului nr.1268 din 08 decembrie 2010 privind aprobarea Programului de protecție și gestiune a monumentelor istorice înscrise în Lista patrimoniului mondial UNESCO modificată prin Hotărârea Guvernului nr.1102 din 2 noiembrie 2011.

7 http://archaeoheritage.ro/legislatie/ (accessed 25.03.2018).

8 http://whc.unesco.org/en/statesparties/ro (accessed 05.03.2018).

9 Concluziile Comisiei de evaluare a propunerilor de revizuire a Listei Indicative a României privind Lista Patrimoniului Mondial UNESCO. Institutul Național al Patrimoniului, 20-21 februarie 2017. 
Table 1. The World Heritage Sites of Romania

\begin{tabular}{|c|l|c|c|}
\hline \multicolumn{1}{|c|}{ World Heritage Site } & Inscribed & Criteria \\
\hline \multicolumn{3}{|c|}{ CULTURAL } \\
\hline 1. & Churches of Moldavia & 1993,2010 & (i)(iv) \\
\hline 2. & Monastery of Hurezi & 1993 & (ii) \\
\hline 3. & $\begin{array}{l}\text { Villages with Fortified Churches } \\
\text { in Transylvania }\end{array}$ & 1993,1999 & (iv) \\
\hline 4. & Dacian Fortresses of the Orăștie Mountains & 1999 & (ii)(iii)(iv) \\
\hline 5. & Historic Centre of Sighișoara NATURAL & 1999 & (iii)(v) \\
\hline 6. & Wooden Churches of Maramureș & 1999 & (iv) \\
\hline \multicolumn{3}{|c|}{1991} & (iv) \\
\hline 7. & Danube Delta & $2007,2011,2017$ & (vii) (x) \\
\hline 8. & $\begin{array}{l}\text { Ancient and Primeval Beech Forests of the } \\
\text { Carpathians and Other Regions of Europe }\end{array}$
\end{tabular}

\section{Debates around the World Heritage Sites}

The debates on cultural heritage research, preservation and management have increased in the recent years as the effect of UNESCO standards, namely to establish "an effective system of collective protection of the cultural and natural heritage of outstanding universal value, organized on a permanent basis and accordance with modern scientific methods". Today, many factors affect the authenticity and integrity of a cultural heritage: intensive tourism, excessive restoration works, new inappropriate investments or uncorrelated private interventions, etc. The problem of preservation, management, and promotion of heritage is of crucial importance from many points of views: scientific, technologic, socio-economic, and cultural. Hence, under UNESCO, took place several debates on the issues concerning monitoring, reporting of the state on the conservation of the World Heritage properties were open, in accordance with Article 29 of the Convention. A consensus was reached in 1997, stating that State Parties have to provide periodic reports on the implementation of the World Heritage Convention and level of conservation of each World Heritage Site. So, every six years, the States Parties are invited to submit to the World Heritage Committee a periodic report on the application of the World Heritage Convention, including the state of conservation of the World Heritage properties located on its territories. Two periodic reports were done (2000-2006 and 2008-2015), and the third one is just launched (2017-2022).

In 1997, after a series of international debates, a consensus was reached stating that States Parties should provide regular reports on the implementation of the World Heritage Convention and the conservation status of each site listed 
on the World Heritage List - in the context of the implementation of the Convention, the World Heritage Committee has set up a reactive monitoring process and a regular reporting process "10.

\section{Reactive monitoring}

Chapter IV of the Operational Guidelines for the Implementation of the World Heritage Convention defines „reactive monitoring”, sets out the objectives of this monitoring, the information received from States signatories to the Convention and / or other sources, the World Heritage Committee decision on the results of reactive monitoring of Sites listed in the Heritage List world. Reactive monitoring is reporting to the Secretariat, other UNESCO sectors, and the Advisory Board of the Committee on the state of preservation of assets on the World Heritage List that are under threat. To this end, States Parties will provide specific reports and impact studies whenever exceptional circumstances arise or work likely to have an impact on the exceptional universal value of the item or on its conservation status. Reactive monitoring also provides procedures for eventual disposal of goods on the World Heritage List ${ }^{11}$. In the context of the recent growth in the role of civil society, NGOs and the community in world heritage protection and rescue, reactive monitoring is increasingly being initiated by the World Heritage Center as a result of the addresses received from them as often States Parties hide realities or avoid reporting certain investment projects that affect the integrity and authenticity of world heritage sites.

\section{Periodic reporting}

The Operational Guidelines details the provisions of Article 20 of the Convention on Reporting. States Parties are therefore invited to send reports to the World Heritage Committee on the legislative and administrative provisions they have adopted and other actions they have taken to implement the Convention, including the conservation status of World Heritage List assets on the World Heritage List. their territory. Point 200 of the Guidelines stipulates that periodic reporting is a self-assessment process and must be conducted by States Parties. The Secretariat coordinates and facilitates the regular reporting process at a global level. States Parties may request expert advice from the Advisory Bodies and the Secretariat, which may also (with agreement of the States

${ }^{10}$ UNESCO, Ghidul operațional de implementare a Convenției patrimoniului mondial, articolul 113, https://whc.unesco.org/en/guidelines/ (accessed 10.08.2018).

${ }^{11}$ IV. Chapter. Process for monitoring the State of conservation of World Heritage Properties. Reactive Monitoring, 169-176, https://whc.unesco.org/en/guidelines/ (accessed 10.08.2018). 
Parties concerned) commission further expert advice. Periodic reporting has four main purposes:

a) to provide an assessment of the application of the World Heritage Convention by the State Party;

b) to provide an assessment as to whether the Outstanding Universal Value of the properties inscribed on the World Heritage List is being maintained over time;

c) to provide up-dated information about the World Heritage properties to record the changing circumstances and state of conservation of the properties;

d) to provide a mechanism for regional co-operation and exchange of information and experiences between States Parties concerning the implementation of the Convention and World Heritage conservation ${ }^{12}$.

Every six years, in accordance with the established geographical order (Arab States, Africa, Asia and the Pacific, Latin America and the Caribbean, Europe and North America), States Parties are invited to submit to the World Heritage Committee a regular report on the application of the World Heritage Convention , including the state of conservation of the sites listed on the World Heritage List located within the territory of each State. The sixth year of each reporting cycle is a period of reflection, evaluation and review of the periodic reporting mechanism before initiating a new cycle. So far, two periodic reports have been made (2000-2006 and 2008-2015) and the third cycle has recently been launched (2017-2022). Chapter V of the Operational Guidelines for the Implementation of the World Heritage Convention describes the objectives, procedure, format, assessment and perspectives of this reporting ${ }^{13}$. The Secretariat of the World Heritage Committee is responsible for organizing the periodic reporting process (28.a) and can be assisted by consultative bodies - ICCROM (International Centre for the Study of the Preservation and Restoration of Cultural Property), ICOMOS (International Council on Monuments and Sites) și IUCN (International Union for Conservation of Nature) (31c).

First Cycle of Periodic Reporting - many State Parties accounted problems in the questionnaire (Section I and II). That's why, during 2005-2007 under auspices of the World Heritage Committee the Working group revised the questionnaire, which was field-tested in 2008 (20 States Parties, 32 properties) and the consolidated version of the questionnaire, including

\footnotetext{
${ }_{12}$ 201. Operational Guidelines..., https://whc.unesco.org/en/guidelines/ (accessed 10.08.2018).

${ }^{13}$ V. Periodic reporting on the implementation of the World Heritage Convention, 199-210, https://whc.unesco.org/en/guidelines/ (accessed 10.08.2018).
} 
comments by States Parties participating in the field testing, was approved by the World Heritage Committee in 2008. So, the questionnaire prepared for the Second Cycle (2008-2015) included Section I - the implementation of the World Heritage Convention at the national level and Section II - concerns each World Heritage property. First Section is done by the Focal Point from each country and should include cultural and natural heritage, but the second section is filled-in by the site manager and then validated by the Focal Point. The full version of the completed questionnaire (Section I and II) has to be submitted to the World Heritage Centre.

The Section I has to include general aspects of Inventories/lists/registers for cultural and natural heritage, Tentative List, Nominations, General Policy Development, Status of Services for Protection, Conservation and Presentation, Scientific and Technical Studies and Research, Financial Status and $\mathrm{Hu}-$ man Resources, Training, International Cooperation, Education, Information and Awareness Building, Conclusions and Recommended Actions, Assessment of the Periodic Reporting Exercise.

The Section II has to cover the situation on each site according to the following structure: World Heritage Property Data, Statement of Outstanding Universal Value, Factors affecting the Property, Protection, Management and Monitoring of the Property, Summary, and Conclusions, Conclusions of the Periodic Reporting Exercise.

The reports concerning the state of conservation of the World Heritage Sites in Romania are done periodically, as it is requested by the World Heritage Centre by the National Institute of Heritage and counties Departments of Cultre. For example, the Dacian fortress Sarmizegetusa Regia benefited from a further assessment of the conservation status when the transfer of the fortress from the Ministry of Culture to the Hunedoara County Council was made. According to the National Heritage Institute data, a number of monitoring reports were carried out at the following sites:

- Churches of Moldavia, in 2011 and 2015;

- Monastery of Hurezi, in 2011 and 2014-2015;

- Villages with Fortified Churches in Transylvania, in 2011 and 2015;

- Dacian Fortresses of the Orastie Mountains, in 2012 and 2015;

- Historic Centre of Sighișoara, in 2007, 2010, 2012 and 2015;

- Wooden Churches of Maramureș, in 2011 and 2014 $4^{14}$

${ }^{14}$ Institutul Național al Patrimoniului, Lista patrimoniuluimondial-UNESCO, https://patrimoniu. ro/monumente-istorice/lista-patrimoniului-mondial-unesco (accessed 1.11.2018). 
According to the UNESCO web page data, Romania presented 23 reports on 4 properties out of the total number of 8 sites. ${ }^{15}$ The main reported aspects regard the changes of the Management systems/management plan (10) and Impacts of tourism/visitor/recreation (8). On the second position, there are issues on Localised utilities (4), Surface water pollution (4), Forestry /wood production (4) and Financial resources (4). Housing (2), Ground transport infrastructure (2), Commercial hunting (2), Legal framework (2) are the third place aspects. Even if the following problems are reported occasionally, I consider they are common for most of the sites and authorities should pay more attention to solve them: Major visitor accommodation and associated infrastructure (1), Effects arising from the use of transportation infrastructure (1), Ground water pollution (1), Subsistence hunting (1), Mining (1), Relative humidity (1), Illegal activities (1), Human resources (1) and Management activities (1).

Table 2. State of conservation of the World Heritage Sites

\begin{tabular}{|c|c|c|}
\hline № & World Heritage Site & Reports on conservation \\
\hline 1. & Danube Delta & $\begin{array}{c}1992,1993,2000,2005,2008, \\
2009\end{array}$ \\
\hline 2. & Churches of Moldavia & $1997,2011,2013$ \\
\hline 3. & Historic Centre of Sighișoara & $\begin{array}{c}2001,2002,2003,2004,2005 \\
2007,2008,2010,2012\end{array}$ \\
\hline 4. & $\begin{array}{l}\text { Ancient and Primeval Beech Forests of the } \\
\text { Carpathians and Other Regions of Europe }\end{array}$ & 2013, 2014, 2015, 2017 \\
\hline 5. & Monastery of Hurezi & No data \\
\hline 6. & Villages with Fortified Churches in Transylvania & No data \\
\hline 7. & Dacian Fortresses of the Orastie Mountains & No data \\
\hline 8. & Wooden Churches of Maramureș & No data \\
\hline
\end{tabular}

Danube Delta reported on water pollution situation, construction of the Giugiurlești oil terminal and the Bâstroe Canal. Churches of Moldavia have reported on problems with humidity and infiltration, deterioration of wall painting, the need for parking facilities and graffiti control. The historic centre of Sighișoara reported on problems with the deterioration of monuments and fortification, the absence of a protection and management plan, poor conservation and protection measures, etc.

In case of Romania, some Periodic Reports from the second Cycle are missing or are just a formality. An example of such a report is the one on Dacian Fortresses of the Orastie Moutans as part of the Second Cycle of Periodic

${ }^{15}$ https://whc.unesco.org/en/soc/?action=list\&id_search_state=134 (accessed on 06.03.2018). 
Reporting (2008-2015) ${ }^{16}$ Report's authors did not reported on many problems which affect the integrity and authenticity of the World Heritage Site. The comments done by Aurora Pețan on this report demonstrate that „Report is full of false and inaccurate data" ${ }^{\prime 7}$. There are 10 positive factors that affect the monument and just one (!) negative, and only potential, not current, namely, religious, ritual activities. Nothing is mentioned about the degradation of the monuments, the parking lot that affected Sarmizegetusa Regia in 2011, or the 2013 floods that affected the same site, or the absence of protection measures, administration (for 5 out of 6 cities by 2013) and a plan management. Ancient sites are affected by a number of natural and human factors such as: animal husbandry, grazing in ancient sites; microorganisms affecting archaeological structures; soil erosion; invasive vegetation; hunting; logging; illegal activities (illegal excavations and looting); climate change, wind, water (rain/water); deliberate destruction; storms; invasive vegetation, etc. But, Aurora Pețan in her critical analysis is pointing that, out of 10 invoked factors, only three are positive, and only partial, two of them being negative at the same time. So, if the reporting was correct, it would have indicated 2-3 positive factors and 15-20 negative instead of 10 positive and one negative. ${ }^{18}$ According to actual situation, only one (Sarmizegetusa Regia) fortress from six has a site manager, scientific council and management plan. Since 2012 the Hunedoara county administration did some steps for improving site management of Sarmizegetusa Regia, access to the site, parking place, supervision with security company, partnership with local police, video system site monitoring, fighting illegal activities, etc. During the last years the number of visitors doubled from 30.000 to 60.000 . Now, the question is how to manage such a big demand. ${ }^{19}$

Although one of the most important issues mentioned in the reports highlighted the management problems, of the six cultural sites in Romania listed in the World Heritage List, a management plan has only the Horezu Monastery

${ }^{16}$ Periodic Report - Second Cycle, Section II Dacian Fortresses of the Orastie Moutans, Monday, October 13,2014, http://whc.unesco.org/archive/periodicreporting/EUR/cycle02/section2/ groupb/906.pdf (accessed 25.03.2018).

${ }^{17}$ Aurora Pețan, Cum îi mințim pe cei de la UNESCO cu privire la cetățile dacice [How we lie to UNESCO about the Dacian fortresses]. 4 decembrie 2015, http://dacica.ro/aurora/cum-iimintim-pe-cei-de-la-unesco-cu-privire-la-cetatile-dacice/ (accessed 25.03.2018).

${ }^{18}$ Aurora Pețan, Evaluare a Raportării Periodice către World Heritage Center (Periodic Reporting Second Cycle) cu privire la Cetățile Dacice din Munții Orăștiei. Alun (Boșorod), jud. Hunedoara, Fundația DACICA, 2016.

${ }^{19}$ Sorin Adrian Vasilescu, Bune practici de administrare la Sarmisegetusa Regia, Seminar „Managementul siturilor UNESCO din România”, București, 30-31 martie 2018. 

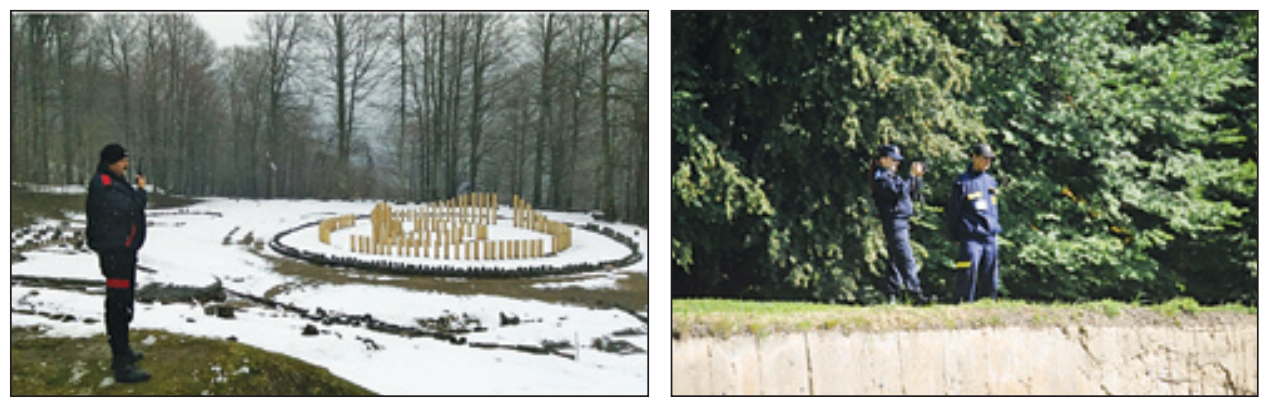

Photo 1-2. Sarmizegetusa Regia site protected by security company and local police (after S.A. Vasilescu)
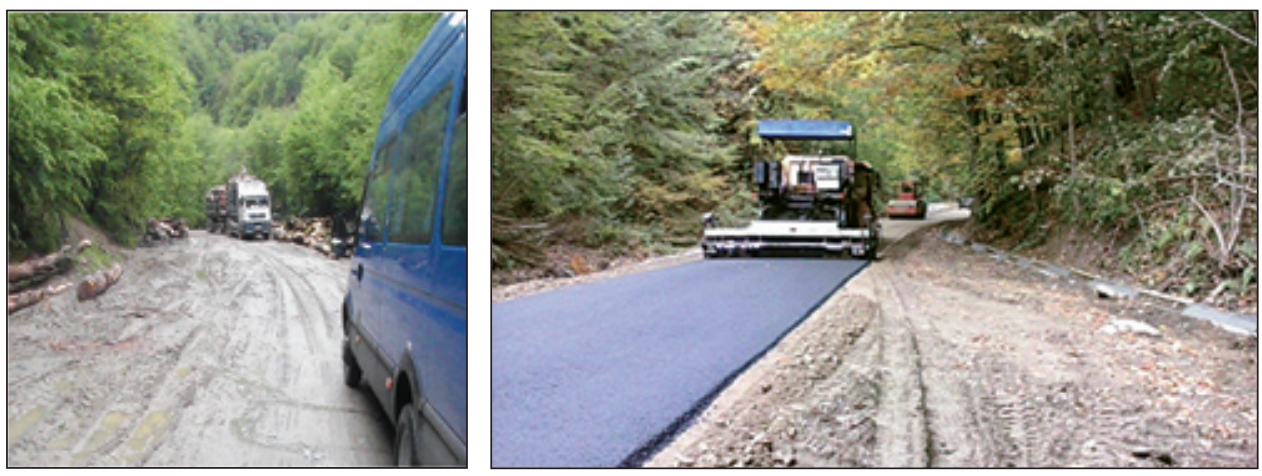

Photo 3-4. The access road to Sarmizegetusa Regia before and after 2012 (after S.A. Vasilescu)

(2013-2019 $)^{20}$. Thus, the lack of documentation required for site management, site manager, specialist staff, clear site status and responsibilities are just a few of the issues that create impediments to the proper management of such assets.

The reports concerning the situation of the World Heritage Sites sometimes are very general. But, such reports have to be a good monitoring tool which could help to improve the management of the site. So, the real problems could be prevented through better monitoring and management methods, while regional cooperation could be a driver for identifying the best solutions. Protection of authentic heritage recognized by UNESCO was recently reconfirmed at the 39th Session of the World Heritage Committee in Bonn, Germany (2015). Participants pointed out the need to review the state of conservation of the World Heritage sites and inscribe new sites into the World Heritage List. In this context, we need a critical approach to the real situation of each site, to start a discussion on a Policy Document for the World Heritage Sites preservation

${ }^{20}$ Lista patrimoniului mondial - UNESCO, https://patrimoniu.ro/monumente-istorice/listapatrimoniului-mondial-unesco (accessed 1.11.2018). 

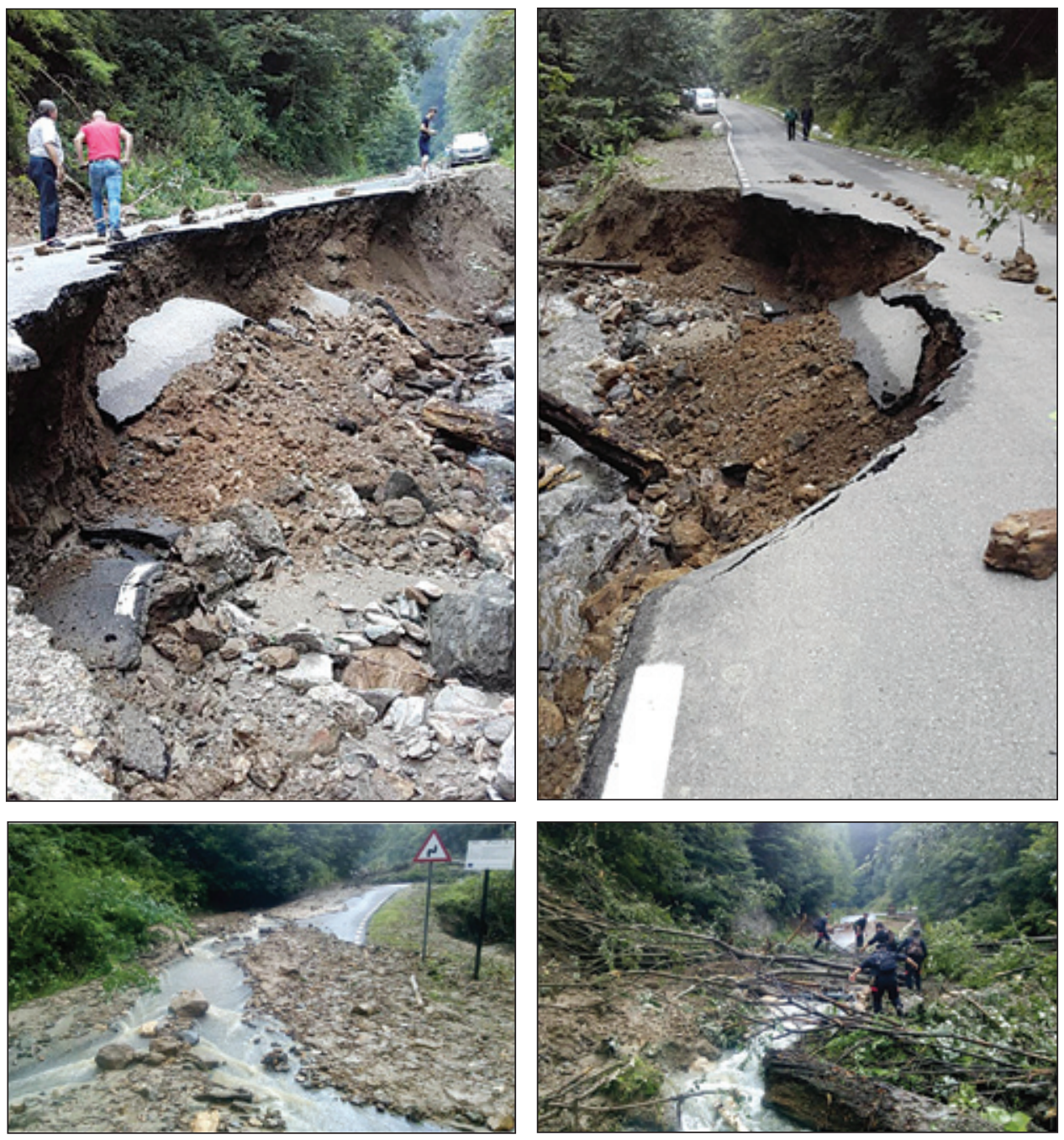

Photo 5-8. The access road to Sarmizegetusa Regia after the Summer calamities 2018

and promotion, and to establish a model for heritage management according to the needs and specificities of each site. The integration approach is the only adequate way to sustainably manage the World Heritage Sites. Furthermore, the need for a relevant, balanced and realistic approach is strongly encouraged by UNESCO in the World Heritage Convention Operational Guidelines.

Because most of the World Heritage Sites from Romania do not have any strategic development and sustainable management plans, I consider there is an acute need for a national report of the evaluation of the UNESCO cultural sites in Romania. There is a significant discrepancy between the visibility and importance given to the sites included on the World Heritage List. These proble- 
ms could be prevented through better monitoring and management methods, while regional cooperation could be a driver for identifying the best ways to do so at a regional level.

Preservation strategies and management plans should be based on the following areas: physical protection, increased visibility, reminders, and references, presentation of the content and site's branding. Cultural sites protection and management should be a dynamic complex approach and follow the principles of the Preservation by Developing Sustainable strategies of the World Heritage List. Sustainable site management should be followed by a permanent consultation process between responsible bodies, in both professional and local communities.

Since 2017, the new decision concerning the World Heritage Sites from Romania has been under debate. The project of the Government decision intends to create an integrated system of regulations - correlated with the UNESCO recommendations; the correlation between direct protection measures and town planning regulations; streamlining, monitoring and management; involvement of local authorities of communities and owners. So, we hope that after approving the new Government Decision, the Management of the World Heritage Sites from Romania will be improved.

\section{Conclusions}

Implementation of the UNESCO 1972 Convention varies from one to another State Parties, but in many countries, there is a misunderstanding of the main goal of the World Heritage Convention which covered cultural and natural heritage. ${ }^{21}$ Romania, from the cultural heritage management point of view, is centralised country, there is a single/national legislation applied to all districts. We hope that during next two years through our project „Preservation by the development of sustainable strategies for a better protection of the UNESCO World Heritage Sites from Romania” - http://archaeoheritage.ro/hero/ it will be possible to identify and set up innovative models of good practices of the World Heritage Sites management and sustainable development.

In March 2017, the United Nations Security Council for the first time in the history of UN adopted Resolution 2347 (2017) confirming the role of cultural heritage in maintaining international peace and security. In this

${ }^{21}$ B. Gaillard, Historical perspective on the transposition of the 1972 UNESCO World Heritage Convention in the national legislation of its states parties. Historical Perspective of Heritage Legislation. Balance between Laws and Values, Tallinn: ICOMOS Estonia, 2017, p. 61. 
context, Irina Bokova, UNESCO Director-General, said that deliberate destruction of heritage is a war crime, heritage attack has become a war tactic to break long-term societies and turned into a strategy of cultural cleansing. Therefore, the defence of cultural heritage is more than a cultural issue, it is a security imperative, inseparable from defending human life. Weapons are not enough to defeat violent extremism. Building peace requires culture, education, prevention, and heritage. ${ }^{22}$ Only a common and integrated approach will make it possible to enrich UNESCO standards of preservation and maintain the World Heritage.

I think, the question of crucial importance for most of the state parties is: How much are the countries prepared for the Third Cycle of Periodic Reporting (2017-2022) and what should they do for better reporting? Because, as it is mentioned in the UNESCO rules, the information provided for Period Reporting will contribute to:

- assessing the state of conservation of World Heritage properties;

- determining whether the Outstanding Universal Value (OUV) of all World Heritage properties has been maintained over time;

- helping to solve outstanding problems and issues through an informed decision-making process;

- sharing experiences, good practices, knowledge and lessons learnt between States Parties, Site Managers and other World Heritage practitioners;

- encouraging cooperation and establishment of networks between partners;

- providing a decision-making tool for States Parties, national institutions, the World Heritage Committee and the World Heritage Centre;

- raising awareness about the World Heritage Convention: in particular the importance of OUV and the concepts of authenticity/integrity. ${ }^{23}$

Romania, along with the states of Europe and North America, members of the Convention, must send regular reports throughout 2021. How prepared is Romania to deal with this new reporting? Have I learned enough from the lessons of previous reports? Are we ready to produce quality reports that reflect reality?

In finally, the Periodic Reports should be an important evaluation tool and guide for improving management plans. As it also calls for the provisions of the World Heritage Convention Operational Guidelines: "Periodic reporting

${ }^{22}$ Resolution 2347 (2017) for the protection of heritage, adopted by the Security Council at its 7907 ${ }^{\text {th }}$ meeting, on March 27 2017. S/Res/2347 (2017). http://en.unesco.org/news/securitycouncil-adopts-historic-resolution-protection-heritage (accessed 25.03.2018)

${ }^{23}$ https://whc.unesco.org/en/periodicreporting/ (accessed 06.04.2018). 
is important for more long-term preservation of registered assets and for strengthening the credibility of the implementation of the Convention. It is also an important tool for assessing the implementation by States Parties of the policies adopted by the World Heritage Committee and the General Assembly. " All the more so as "the periodic reporting process is used as an opportunity for regional exchange and cooperation and to enhance active coordination and synchronization among States Parties, especially in the case of cross-border and transnational goods" 24 .

\section{Acknowledgements}

This research is part of the Project „Preservation by the development of sustainable strategies for better protection of the UNESCO World Heritage Sites from Romania" - archaeoheritage.ro/hero, supported by the National Research Council (CNCS) - Executive Agency for Higher Education, Research, Development and Innovation Funding (UEFISCDI), PN-III-P4-ID-PCE-2016-0737 and implemented under the auspices of the Institute of Archaeology of the Romanian Academy, Iași Branch, Romania.

\section{References}

Gaillard B. (2017). Historical perspective on the transposition of the 1972 UNESCO World Heritage Convention in the national legislation of its states parties. Historical Perspective of Heritage Legislation. Balance between Laws and Values, 56-62. Tallinn: ICOMOS Estonia.

Francioni, F. and F. Lenzerini (2008). The 1972 World Heritage Convention: a commentary. Oxford: Oxford University Press.

INP (2017) = Institutul Național al Patrimoniului. Concluziile Comisiei de evaluare a propunerilor de revizuire a Listei Indicative a României privind Lista Patrimoniului Mondial UNESCO. Institutul Național al Patrimoniului, 20-21 februarie 2017. Bucharest.

INP (2018) = Institutul Național al Patrimoniului, Lista patrimoniului mondial UNESCO. Online: patrimoniu.ro/monumente-istorice/lista-patrimoniuluimondial-unesco

RoGov (2004) = Romanian Government. "Hotărârea Guvernului nr. 493/2004 pentru aprobarea Metodologiei privind monitorizarea monumentelor istorice înscrise în Lista patrimoniului mondial și a Metodologiei privind elaborarea și conținutul-cadru al planurilor de protecție și gestiune a monumentelor istorice înscrise în Lista patrimoniului mondial”.

RoGov (2008) = Romanian Government. "Hotărârea Guvernului nr. 738/2008 privind stabilirea măsurilor necesare în vederea finanțării, elaborării și actualizării

${ }^{24} 202$ and 205bis. Operational Guidelines..., https://whc.unesco.org/en/guidelines/ (accessed 10.08.2018). 
documentațiilor de amenajare a teritoriului şi urbanism pentru zonele $\mathrm{cu}$ monumente istorice care fac parte din Lista Patrimoniului Mondial".

RoGov (2010) = Romanian Government. "Hotărârea Guvernului nr.1268 din 08 decembrie 2010 privind aprobarea Programului de protecție şi gestiune a monumentelor istorice înscrise în Lista patrimoniului mondial UNESCO”.

RoGov (2011) = Romanian Government. "Hotărârea Guvernului nr.1102 din 2 noiembrie 2011 pentru modificarea Programului de protecție şi gestiune a monumentelor istorice înscrise în Lista patrimoniului mondial UNESCO, aprobat prin Hotărârea Guvernului nr. 1.268/2010”.

RoParl $(2001)=$ Romanian Parliament. "Legea 564/2001 pentru aprobarea și modificarea OG $47 / 2000$ privind stabilirea unor măsuri de protecție a monumentelor istorice care fac parte din Lista Patrimoniului Mondial”.

UN (2017) = United Nations. "Resolution 2347 (2017) for the protection of heritage, adopted by the Security Council at its $7907^{\text {th }}$ meeting, on March 27 2017”. S/ Res/2347.

UNESCO $(2017 \mathrm{a})=$ UNESCO World Heritage Centre. Basic Texts of the 1972 World Heritage Convention. Paris.

UNESCO $(2017 \mathrm{~b})=$ UNESCO World Heritage Centre. The Operational Guidelines for the Implementation of the World Heritage Convention. Online: whc.unesco.org/ en/guidelines.

UNESCO $(2018 \mathrm{a})=$ UNESCO World Heritage Centre. State of Conservation Information System. Online: whc.unesco.org/en/soc/.

UNESCO $(2018 b)=$ UNESCO World Heritage Centre. "Periodic Report - Second Cycle, Section II Dacian Fortresses of the Orastie Moutans, Monday, October 13, 2014". Online: whc.unesco.org/archive/periodicreporting/EUR/cycle02/ section $2 /$ groupb/906.pdf.

UNESCO (2018c) = UNESCO World Heritage Centre. "Periodic Reporting". Online: whc.unesco.org/en/periodicreporting/.

UNESCO (2018d) = UNESCO World Heritage Centre. "States Parties Ratification Status - Romania”. Online: whc.unesco.org/en/statesparties/ro.

Pețan, A. (2015). Cum îi mințim pe cei de la UNESCO cu privire la cetățile dacice. In: dacica.ro, 4 December 2015. Online: dacica.ro/aurora/cum-ii-mintim-pe-cei-dela-unesco-cu-privire-la-cetatile-dacice/.

Pețan, A. (2016). Evaluare a Raportării Periodice către World Heritage Center (Periodic Reporting - Second Cycle) cu privire la Cetățile Dacice din Munții Orăștiei. Alun: Fundația DACICA.

Vasilescu, S.A. (2018). "Bune practici de administrare la Sarmisegetusa Regia”. In: Seminar „Managementul siturilor UNESCO din România”, București, 30-31 martie 2018. 


\section{Starea de conservare și raportarea periodică - o modalitate de protejare și dezvoltare mai durabilă a siturilor de patrimoniu mondial}

\section{Rezumat}

Din 1972, UNESCO a instituit un cadru de protecție pentru patrimoniul cultural și natural (Convenția privind protecția patrimoniului cultural și natural mondial) și „Lista patrimoniului mondial”, pe care o consideră ca având o valoare universală deosebită. În 1994, la Conferința de la Nara, a fost înființat Documentul privind autenticitatea, precizând că „protejarea și îmbunătățirea diversității culturale și a patrimoniului din lumea noastră ar trebui promovată activ ca un aspect esențial al dezvoltării umane”. Astăzi, mulți factori afectează autenticitatea și integritatea patrimoniului cultural: turism intensiv, lucrări de restaurare excesive, noi investiții necorespunzătoare sau intervenții private necorelate etc. Problema conservării, gestionării și promovării patrimoniului este de o importanță crucială din mai multe puncte de vedere: științifice, tehnologice, socio-economice și culturale. România deține opt proprietăți care fac parte din Lista Patrimoniului Mondial (două situri naturale și șase situri culturale). Alte șaptesprezece proprietăți sunt incluse în lista indicativă. Rapoartele referitoare la situația siturilor de patrimoniu mondial în România sunt realizate periodic, dar majoritatea sunt doar o formalitate fără niciun fel de dezvoltare strategică şi planuri de management. Există o discrepanță semnificativă între vizibilitatea și importanța acordată siturilor incluse pe lista patrimoniului mondial. Aceste probleme ar putea fi prevenite prin metode de monitorizare și gestionare mai bune, în timp ce cooperarea regională ar putea fi una dintre modalitîtîle cele mai potrivite pentru un management eficient. Deoarece, doar o abordare comună şi integrată va face posibilă respectarea standardelor UNESCO de conservare și menținerea statutului de patrimoniu mondial.

Cuvinte cheie: Lista patrimoniului mondial, managementul patrimoniului, starea de conservare, evaluare, monitorizare, România, UNESCO

Sergiu Musteață, Romanian Academy — Iași Institute of Archaeology, e-mail:sergiu_musteata@yahoo.com 